\title{
Effect of concurrent training on risk factors and hepatic steatosis in obese adolescents
}

\author{
Efeito do treinamento concorrente sobre fatores de risco e esteatose hepática em adolescentes obesos \\ Efecto del entrenamiento concurrente sobre factores de riesgo y esteatosis hepática en adolescentes obesos
}

Barbara de Moura M. Antunes ${ }^{1}$, Paula Alves Monteiro², Loreana Sanches Silveira², Suziane Ungari Cayres³, Camila Buonani da Silva4, Ismael Forte F. Júnior ${ }^{5}$

\section{ABSTRACT}

Objective: To analyze the effects of a 20-week concurrent training on the variables of body composition, lipid profile, and fatty liver diagnosis in obese adolescents.

Methods: An open clinical trial was carried out with 34 obese adolescents aged between 12 and 15 years. Total body fat, trunk fat mass, total cholesterol and its fractions (HDL, LDL and VLDL), and triglycerides were analyzed; an upper abdominal ultrasound was performed in order to diagnose fatty liver. The participants underwent concurrent training (association of weight training with aerobic training) three times per week, lasting one hour for 20 weeks. Statistical analysis included paired Student's $t$-test and frequency analysis in order to verify the relative and absolute reductions of fatty liver diagnosis, being significant $p<0.05$.

Results: The studied adolescents showed statistically significant improvement in body composition, with a decrease of total body fat percentage, total fat mass, trunk fat, and an a increase in the lean body mass. They also presented reduced size of liver lobes, decrease in total cholesterol and in LDL-cholesterol, with a lower prevalence of fatty liver.

Conclusions: The concurrent training was effective for promoting significant improvements in body fat composition and lipid profile variables, besides reducing fatty liver prevalence rate.

Key-words: training; obesity, fatty liver; body composition; lipids; clinical trial.

\section{RESUMO}

Objetivo: Analisar os efeitos de 20 semanas de treinamento concorrente sobre as variáveis de composição corporal, perfil lipídico e diagnóstico da esteatose hepática em adolescentes obesos.

Métodos: Realizou-se um ensaio clínico aberto com 34 adolescentes obesos com idades entre 12 e 15 anos. Foram analisados gordura corporal total e de tronco, colesterol total e suas frações (HDL, LDL e VLDL) e triglicérides, sendo realizado exame de ultrassonografia de abdome superior para diagnosticar esteatose hepática. Os participantes foram submetidos ao treinamento concorrente (associação de treino com pesos e exercício aeróbio) três vezes por semana, com duração de uma hora-aula durante 20 semanas. Para o tratamento estatístico, foram realizados o teste $t$ de Student pareado e a análise de frequência, a fim de verificar as reduções relativa e absoluta do diagnóstico da esteatose hepática, adotando-se $p<0,05$.

Resultados: Os adolescentes estudados apresentaram melhoras significativas da composição corporal, com diminuição do percentual de gordura total, da massa gorda total, da gordura de tronco e do aumento da massa magra, além de redução do tamanho dos lóbulos do fígado, dos índices de prevalência da esteatose hepática, do colesterol total e LDL-colesterol.

Conclusões: $\mathrm{O}$ treinamento concorrente foi efetivo por promover melhorias significativas de variáveis da composição
Instituição: Universidade Estadual Paulista "Júlio de Mesquita Filho" (Unesp) - Campus de Presidente Prudente, Presidente Prudente, SP, Brasil ${ }^{1}$ Mestranda em Ciências da Motricidade na Unesp, Rio Claro, SP, Brasil ${ }^{2}$ Mestre em Fisioterapia pela Unesp, Presidente Prudente, SP, Brasil ${ }^{3}$ Graduanda em Educação Física pela Unesp, Presidente Prudente, SP, Brasil ${ }^{4}$ Doutoranda em Ciências da Motricidade pela Unesp, Rio Claro, SP, Brasil ${ }^{5}$ Livre-Docente pela Unesp; Professor Adjunto do Departamento de Educação Física da Unesp, Presidente Prudente, SP, Brasil

\author{
Endereço para correspondência: \\ Barbara de Moura M. Antunes \\ Rua Roberto Simonsen, 305 - Santa Helena \\ CEP 19060-900 - Presidente Prudente/SP \\ E-mail: bah_tunes@hotmail.com \\ Fonte financiadora: Conselho Nacional de Desenvolvimento Científico e \\ Tecnológico (CNPq), 18531 \\ Conflito de interesse: nada a declarar \\ Recebido em: 22/5/2012 \\ Aprovado em: 11/10/2012
}


corporal e do perfil lipídico, além de reduzir a prevalência da esteatose hepática.

Palavras-chave: treinamento; obesidade; esteatose hepática; composição corporal, lipídeos; ensaio clínico.

\section{RESUMEN}

Objetivo: Analizar los efectos de 20 semanas de entrenamiento concurrente sobre las variables de composición corporal, perfil lipídico y diagnóstico de la esteatosis hepática en adolescentes obesos.

Métodos: Se realizó un ensayo clínico abierto con 34 adolescentes obesos con edades entre los 12 y los 15 años $(13,7 \pm 1,17)$. Se analizaron grasa corporal total y de tronco, colesterol total y sus fracciones (HDL, LDL y VLDL) y triglicéridos, siendo realizado examen de ultrasonografía abdominal superior para diagnosticar esteatosis hepática. Los participantes fueron sometidos al entrenamiento concurrente (asociación de entrenamiento con pesos y ejercicio aeróbico) tres veces por semana, con duración de una hora clase durante 20 semanas. Para el tratamiento estadístico, se realizaron análisis descriptivo, prueba t de Student pareada y análisis de frecuencia, a fin de verificar las reducciones relativa y absoluta del diagnóstico de la esteatosis hepática, adoptando $p<0,05$.

Resultados: Los adolescentes estudiados presentaron mejoras significativas de la composición corporal, con reducción del porcentaje de grasa total, de la masa gorda total, de la grasa de tronco y del aumento de masa magra, además de reducción del tamaño de los lóbulos del hígado, de los índices de prevalencia de la esteatosis hepática, del colesterol total y del LDL-colesterol.

Conclusiones: El entrenamiento concurrente fue efectivo por promover mejorías significativas de variables de la composición corporal y del perfil lipídico, además de reducir la prevalencia de la esteatosis hepática.

Palabras clave: entrenamiento; obesidad; esteatosis hepática; composición corporal; lípidos; ensayo clínico.

O número de registro do caso clínico é RBR-4HN597, (http://www.ensaiosclinicos.gov.br).

\section{Introduction}

Over the last decades, obesity has become a public health issue, since it is the most prevalent nutritional disorder in adults and children ${ }^{(1,2)}$. This disorder alone is considered a risk factor for the development of several diseases, such as dyslipidemia and fatty liver (FL). The latter has been calling the attention of specialists due to its high prevalence among obese individuals ${ }^{(3)}$.

FL represents a spectrum of liver disorders that are histologically unified by macrovesicular fatty liver in the absence of excessive alcohol intake ${ }^{(4)}$; however, it can cause liver cirrhosis and even liver carcinoma if not treated in time $e^{(5,6)}$.

Dyslipidemia is characterized by alterations in the plasma levels of one or more lipids or lipoproteins, e.g., triglycerides, total cholesterol and its fractions (HDL- and LDL-cholesterol ${ }^{(7)}$. Since obesity is one of the main risk factors for the development of dyslipidemia and $\mathrm{FL}^{(8,9)}$, the reduction in body weight with non-pharmacological interventions is the most accepted method for the majority of population, including the pediatric one. These interventions are based on dietary reeducation and regular physical activity, which is the focus of several studies that aimed to identify which training models are more effective in the treatment of obesity and related diseases.

From this perspective, concurrent training has been proposed as a treatment for obesity and its complications, consisting of a training program that combines weight and aerobic exercises in the same session ${ }^{(10)}$. Strength exercises are responsible for improvements in body composition, such as an increase in bone and lean masses as well as a reduction in total body weight and absolute and relative fat mass ${ }^{(11)}$. In parallel to this, aerobic exercises collaborate in the reduction and control of total body fat ${ }^{(12,13)}$ and promote beneficial changes in individuals' lipid profile by reducing lipoproteins and triglycerides and increasing HDL-cholesterol ${ }^{(14)}$.

Thus, the aim of this study was to analyze the effects of a 20-week concurrent training program on the variables of body composition, lipid profile and fatty liver diagnosis in obese adolescents.

\section{Method}

The present study is an open clinical trial carried out in 2010 in the city of Presidente Prudente, located in the western region of São Paulo state, Brazil. This study used the following inclusion criteria:

- Classification of obesity according to the pediatric body mass index (BMI) for age and gender, based on the criteria published by Cole et $a l^{(15)}$, and to waist circumference (WC), based on the criteria by Taylor $e t a l^{(16)}$. 
- Age between 12 and 15 years on the day of assessment.

- Absence of clinical conditions that made physical activities impossible.

- A free and informed consent for participation in the program signed by the parents or legal guardians.

Patients who missed three consecutive sessions were removed from the extension program.

Subjects participated in a program for the treatment of obesity aimed at children and adolescents aged between 6 and 15 years that was conducted at the Science and Technology Faculty, which is on the Presidente Prudente campus of the Universidade Estadual Paulista (FCT/Unesp).

Participants were screened by body composition assessment and, after initial measurements were taken, blood tests and upper abdominal ultrasound were scheduled. Both evaluations were conducted at specialized facilities in the city of Presidente Prudente.

All care was taken concerning ethical issues. Subjects were invited to take part voluntarily in the study and, along with their parents or legal guardians, were informed in detail about the study objectives and about how data would be collected. Only subjects who provided a signed free and informed consent were enrolled. The study was approved by the Research Ethics Committee at the FCT/Unesp, under protocol number 07/2009.

Body mass was measured using a Filizola mechanical balance (Filizola S.A Pesagem e Automação, São Paulo, Brazil), accurate to $0.1 \mathrm{~kg}$, and height was measured using a fixed, wooden stadiometer, accurate to $0.1 \mathrm{~cm}$. Based on these measurements, we calculated BMI.

Total body and trunk fat were estimated using a Lunar DPX-NT (Lunar/GE Corp, Madison, Wisconsin) double emission X-ray absorptiometry machine. Body fat percentage (BF\%), total fat mass (TFM), lean body mass (LBM), and trunk fat percentage (TF\%) were measured. Trunk fat mass was classified according to the age and sex specific references proposed by Taylor $e t a l^{(16)}$.

Blood tests were conducted at a specialized laboratory in order to characterize lipid variables, after 12 hours' fasting, and measured triglycerides, total cholesterol and its fractions (HDL, LDL, VLDL), according to the reference values proposed in the III Brazilian Guidelines on Dyslipidemias of the Brazilian Society of Cardiology ${ }^{(17)}$.

Upper abdominal ultrasound scan was performed according to medical and literature recommendations, with four hours' fasting, in order to diagnose FL and measure the thickness of right (RL) and left lobes (LL) of liver and intraabdominal (IAF) and subcutaneous fat (SF).

During the 20 weeks of the study, adolescents trained three times per week for one hour per session/day. At the beginning of activities, there was a four-week period of neuromuscular adaptation, both for aerobic activities and resistance exercises, and after this period the intensity of effort was monitored by a Polar heart rate monitor (Heart Rate Monitor, model S810, Finland). The equipment was used to guarantee that participants spent $70 \%$ of the time in the aerobic zone ( 65 to $85 \%$ of maximum heart rate). As for weight training, maximum loads were estimated by the 12-repetition maximum test, in order to establish the intensity of training aimed at muscular strengthening (between 65 and $75 \%$ of maximum repetition value).

The concurrent training consisted of 30 minutes of aerobic activities (walking or running) and 30 minutes of resistance work with weight exercises, which was performed at the university gym with the purpose of developing the strength of several muscular groups (legs, arms, abdomen, pectoral, shoulder, back, and hip).

Resistance exercises were developed in the form of circuit and each station comprised the following activities: leg press at $45^{\circ}$, dorsal, triceps extension, hack squat, incline bench press, lateral raise, leg curl, arm curl, leg extension, sit-up, seated row, and chest press. Each station was performed once, with sets of 15 to 20 repetitions and one to two-minute rest between exercises, and sit-ups were performed on the ground using only body weight.

Statistical treatment was carried out using descriptive analysis, in which the values obtained were expressed as mean and standard deviation. Paired Student's $t$ test was used to compare variables before and after intervention. Wilcoxon's test was used to analyze the effect of the intervention on the degrees of FL. An additional analysis was run with the McNemar's test to verify the effect of the intervention on those subjects who had some degree of the disease at the start of the study. Analyses were performed using Statistical Package for the Social Sciences (SPSS) software, version 17.0 (Inc. Chicago. IL). Statistical significance was set at 5\%.

\section{Results}

The study included 34 obese adolescents, 12 of which were girls and 22 were boys, with ages between 12 and 15 years $(13.7 \pm 1.17)$. Table 1 presents means and standard deviations before and after 20 weeks' intervention, showing a 
Table 1 - Anthropometric indices and blood analyses before and after intervention, described as mean \pm standard deviation

\begin{tabular}{lccc}
\hline Variables & $\begin{array}{c}\text { Before intervention } \\
(\mathbf{n}=\mathbf{3 4})\end{array}$ & $\begin{array}{c}\text { After intervention } \\
(\mathbf{n}=\mathbf{3 4})\end{array}$ & $\boldsymbol{p}$-value \\
\hline Age (years) & $13.6 \pm 1.0$ & $13.6 \pm 1.1$ & 0.910 \\
Body mass $(\mathrm{kg})$ & $77.4 \pm 15.6$ & $77.5 \pm 12.1$ & 0.960 \\
Height $(\mathrm{cm})$ & $161.6 \pm 7.9$ & $163.4 \pm 7.9$ & $<0.001$ \\
BMI $\left(\mathrm{kg} / \mathrm{m}^{2}\right)$ & $29.5 \pm 5.1$ & $28.9 \pm 3.4$ & 0.350 \\
BF\% DEXA & $44.1 \pm 5.7$ & $40.6 \pm 5.5$ & $<0.001$ \\
FM $(\mathrm{kg})$ & $34.3 \pm 7.1$ & $31.1 \pm 6.9$ & $<0.001$ \\
LBM $(\mathrm{kg})$ & $40.5 \pm 7.2$ & $42.6 \pm 7.5$ & $<0.001$ \\
TF\% & $45.9 \pm 6.1$ & $41.4 \pm 6.5$ & $<0.001$ \\
RL $(\mathrm{cm})$ & $13.5 \pm 1.2$ & $13.0 \pm 1.1$ & 0.010 \\
LL $(\mathrm{cm})$ & $9.0 \pm 1.4$ & $8.1 \pm 1.3$ & $<0.001$ \\
SF $(\mathrm{cm})$ & $3.5 \pm 1.3$ & $3.4 \pm 0.9$ & 0.640 \\
IAF $(\mathrm{cm})$ & $4.1 \pm 1.5$ & $3.9 \pm 1.4$ & 0.390 \\
TG & $113.2 \pm 59.2$ & $103.6 \pm 51.5$ & 0.080 \\
Total cholesterol & $165.6 \pm 36.8$ & $146.5 \pm 31.7$ & $<0.001$ \\
HDL & $43.1 \pm 10.3$ & $42.4 \pm 8.9$ & 0.510 \\
VLDL & $22.7 \pm 11.8$ & $20.7 \pm 10.3$ & 0.080 \\
LDL & $99.7 \pm 32.1$ & $83.3 \pm 28.3$ & $<0.001$ \\
\hline BL
\end{tabular}

BMI: body mass index; BF\% DEXA: body fat percentage by DEXA; FM: fat mass; LBM: lean body mass; TF\%: trunk fat percentage; RL: right lobe of liver; LL: left lobe of liver; SF: subcutaneous fat; IAF: intra-abdominal fat; TG: triglycerides; HDL: high density lipoprotein; VLDL: very-low density lipoprotein; LDL: low-density lipoprotein;

Table 2 - Prevalence of individuals with fatty liver according to degree of severity before and after intervention, based on ultrasound classification

\begin{tabular}{lcrcrc}
\hline \multirow{2}{*}{ FL } & \multicolumn{2}{c}{ Before intervention } & \multicolumn{2}{c}{ After intervention } & \multirow{2}{*}{$\boldsymbol{p}$-value } \\
\cline { 2 - 5 } & $\mathbf{n}$ & $\boldsymbol{\%}$ & $\mathbf{n}$ & $\boldsymbol{\%}$ & \\
\hline Degree 0 & 25 & 73.5 & 28 & 82.4 & 0.50 \\
Degree 1 & 6 & 17.6 & 5 & 14.7 & 0.06 \\
Degree 2 & 2 & 5.9 & 1 & 2.9 & 0.50 \\
Degree 3 & 1 & 2.9 & - & - & $*$ \\
Total & 34 & 100 & 34 & 100 & - \\
\hline
\end{tabular}

FL: fatty liver; Degree 0: absence of the disease; Degree 1: mild stage; Degree 2: moderate stage; Degree 3: severe stage; n: number of individuals; *statistical analysis could not be performed

significant increase in height and LBM $(\mathrm{kg})$ simultaneously with a decrease in TFM $(\mathrm{kg}), \mathrm{BF} \%$, TF\%, RL, LL, total cholesterol, and LDL.

Table 2 presents absolute and relative values for FL prevalence before and after the 20 weeks of intervention, divided into degrees of disease severity, showing an absolute and relative reduction in the prevalence of the disease, although with no statistical significance. In addition, when only individuals with abnormal liver results were analyzed, it was observed that, of the nine adolescents with $\mathrm{FL}$ at the start of the study, eight of them $(88.9 \%)$ had a reduction in the degree of disease severity after the intervention $(p=0.008)$.

\section{Discussion}

Epidemiological studies suggest that excess adiposity in the pediatric population is a risk factor for the development of several metabolic disorders, such as FL, which can worsen in adulthood if not treated early ${ }^{(18,19)}$.

Evidence suggests that FL affects $2.6 \%$ of children and $9.6 \%$ of adolescents, and its worldwide prevalence in the obese pediatric population ranges from 12 to $80 \%{ }^{(20,21)}$. In the United States, this prevalence ranges from 42 to $77 \%$ in obese children and adolescents between 8 and 18 years ${ }^{(22)}$, and from 6 to $23 \%$ in overweight children ${ }^{(23)}$. 
The present study aimed to verify the effect of a 20week intervention program of concurrent training on body composition, lipid profile and FL diagnosis in an obese pediatric population. The practice of regular and systematized physical activity is proposed as a method for preventing and treating obesity and its associated diseases, helping in the reversion of metabolic and hemodynamic changes and showing good acceptance among different populations ${ }^{(24)}$.

The study evidenced significant changes, with an increase in lean mass and a reduction in fat mass simultaneously with $\mathrm{BF} \%$, with emphasis on TF\%, total cholesterol, LDL-cholesterol and liver lobes after the intervention period. The literature provides evidence that there was an inverse relationship between energy expenditure from systematized and regular physical activity and the accumulation of fat; therefore, it is observed that the practice of exercises, especially aerobic exercises, helps to reduce body weight and fat percentage, besides helping to increase lean and bone masses and promoting improvements in metabolic aspects ${ }^{(25)}$.

In a study similar to ours, Foschini et al ${ }^{(26)}$ analyzed the efficacy of a 14-week multidisciplinary treatment in postpuberal obese adolescents who underwent concurrent training and observed a significant reduction in the variables of body composition, such as $\mathrm{BMI}, \mathrm{BF} \%$, body mass, subcutaneous and intra-abdominal fat, as well as a decrease in biochemical and hemodynamic variables. A study by Leite et $a^{(12)}$ with obese children demonstrates significant improvements in body composition conferred by physical activity and nutritional counseling, explaining the importance of a multiprofessional approach for the treatment of obesity.

In the present work it was observed that the intervention with concurrent training was effective in the treatment of FL, since there was an improvement in the diagnosis of this disease in the analyzed sample, as shown in Table 2. The reduction in the number of adolescents with FL may be explained by the decrease in the values of trunk fat and by the improvement in the lipid profile. However, only LDL-cholesterol had a statistically significant reduction.

In a research conducted by Dâmaso et al ${ }^{(27)}$ to verify the effect of a multidisciplinary treatment with obese adolescents who performed aerobic exercises and gymnastics for 12 weeks, it was observed a significant decrease in total body mass and subcutaneous fat as well as a reduction in FL prevalence both for RL and LL, although with no statistical significance. Such findings were also reported in the present investigation; notwithstanding, the study population showed a significant reduction in the size of liver lobes, which may have contributed to reduce the presence of FL in the adolescents.

It is known that continuous and systematic training leads to a decrease in serum levels of triglycerides, total cholesterol and LDL-cholesterol, besides increasing HDL-cholesterol levels and lean mass ${ }^{(28)}$. Such results were found in this study, which showed a significant reduction in total cholesterol and LDL-cholesterol and an increase in HDL-cholesterol levels, although not statistically significant in both groups.

The data from the present study are important to elucidate the effects of a training intervention on obesity and FL. However, it is necessary to mention that this study has limitations, such as the lack of nutritional counseling accompanying the proposed training and the small sample size. Additionally, the scarcity of studies analyzing the effects of concurrent training in the pediatric population makes it difficult to compare different samples.

Based on the results obtained, it can be concluded that concurrent training was effective for promoting the reduction in FL prevalence, the decrease in the size of liver lobes, and some changes in body composition parameters, with the reduction in $\mathrm{BF} \%$, fat mass, fat trunk percentage and the increase in lean body mass, besides leading to improvements in variables of lipid profile.

\section{Acknowledgements}

We would like to thank the National Council for Scientific and Technological Development (Conselho Nacional de Desenvolvimento Científico e Tecnológico, $\mathrm{CNPq}$ ), the Department of Physical Education at FCT-Unesp, and the Motor Activity Assessment and Prescription Laboratory (Centro e Laboratório de Prescrição de Atividade Motora, Celapam), and their members. Furthermore, we are grateful to the reviewers and professors for the suggestions made during the writing of the manuscript. 


\section{References}

1. Ogden $\mathrm{CL}$, Carroll MD, Kit BK, Flegal KM. Prevalence of obesity and trends in body mass index among US children and adolescents, 1999-2010. JAMA 2012;307:483-90.

2. Ferrari HG, Barbosa MH. Prevalence of overweight and obesity in pertaining to school of the basic education of public schools of Limeira, São Paulo. Conexões 2008;6:234-42.

3. Targher G, Arcaro G. Non-alcoholic fatty liver disease and increased risk of cardiovascular disease. Atherosclerosis 2007;191:235-40.

4. Padoin AV, Staub HL, Chatkin JM, Moreto M, Maggioni L, Rizzolli J et al. Nonalcoholic fatty liver disease and risk of cirrhosis. Scientia Med 2008;18:172-6.

5. Chaves GV, Pereira SE, Saboya CJ, Cortes C, Ramalho R. Ultrassonografia e ressonância magnética: estudo comparativo no diagnóstico da esteatose em obesos grau III. Rev Assoc Med Bras 2009;55:45-9.

6. Soder RB, Baldisserotto M. Hepatic steatosis in obese children: imaging investigation. Scientia Med 2009;19:202-8.

7. Fernandes RA, Christofaro DG, Casonatto J, Codogno JS, Rodrigues E, Cardoso $\mathrm{M}$ et al. Prevalence of dyslipidemia in individuals physically active during childhood, adolescence and adult age. Arq Bras Cardiol 2011;97:317-23.

8. Gholam PM, Flancbaum L, Machan JT, Charney DA, Kotler DP. Nonalcoholic fatty liver disease in severely obese subjects. Am J Gastroenterol 2007;102:399-408.

9. Nobili V, Alisi A, Raponi M. Pediatric non-alcoholic fatty liver disease: preventive and therapeutic value of lifestyle intervention. World J Gastroenterol 2009;15:6017-22.

10. Andrade NV, Gonçalves RN, Monteiro LL, Pereira EF. Concurrent training: a review. Ensaios e Ciência 2008;12:17-33.

11. Oliveira CL, Mello MT, Cintra IP, Fisberg M. Obesity and metabolic syndrome in infacy and adolescence. Rev Nutr 2004;17:237-45.

12. Leite N, Lazarotto L, Cavazza JF, Lopes MF, Bento PC, Torres R et al. Effects of aquatic exercise and nutritional guidance on the body composition of obese children and adolescents. Rev Bras Cineantropom Desempenho Hum 2010;12:232-8.

13. McArdle WD, Katch Fl, Katch VL. Essentials of exercise physiology. $2^{\text {nd }}$ ed. Philadelphia: Lippincott Williams \& Wilkins; 2000.

14. Slentz CA, Houmard JA, Johnson JL, Bateman LA, Tanner CJ, McCartney JS et al. Inactivity, exercise training and detraining, and plasma lipoproteins STRRIDE: a randomized, controlled study of exercise intensity and amount. J Appl Physiol 2007;103:432-42.

15. Cole TJ, Bellizzi MC, Flegal KM, Dietz WH. Establishing a standard definition for child overweight and obesity worldwide: international survey. BMJ 2000;320:1240-3.
16. Taylor RW, Jones IE, Williams SM, Goulding A. Evaluation of waist circumference, waist-to-hip ratio, and the conicity index as screening tools for high trunk fat mass, as measured by dual-energy X-ray absorptiometry, in children aged 3-19y. Am J Clin Nutr 2000;72:490-5.

17. Autoria não referida. III Diretrizes Brasileiras sobre Dislipidemias e Diretriz de Prevenção da Aterosclerose do departamento de Aterosclerose da Sociedade Brasileira de Cardiologia. Arq Bras Cardiol 2001;77:1-48.

18. Mantovani RM, Viana MF, Cunha SB, Moura LC, Oliveira JM, Carvalho FF et al. Obesidade na infância e adolescência. Rev Med Minas Gerais 2008;18 (4 Suppl 1):107-18.

19. Netto-Oliveira ER, Oliveira AA, Nakashima AT, Rosaneli CF, Oliveira Filho A, Rechenchosky $L$ et al. Overweight and obesity in children of different socioeconomic levels. Rev Bras Cineantropom Desempenho Hum 2010;12:83-9.

20. Padilha PC, Rocha HF, Alves N, Peres WA. Prevalence of nonalcoholic fatty liver disease in obese children and adolescents: a systematic review. Rev Paul Pediatr 2010;28:387-93.

21. Mathur P, Das MK, Arora NK. Non-alcoholic fatty liver disease and childhood obesity. Indian J Pediatr 2007;74:401-7.

22. Sagi R, Reif S, Neuman G, Webb M, Phillip M, Shalitin S. Nonalcoholic fatty liver disease in overweight children and adolescents. Acta Paediatr 2007;96: 1209-13.

23. Schwimmer JB, McGreal N, Deutsch R, Finegold MJ, Lavine JE. Influence of gender, race, and ethnicity on suspected fatty liver in obese adolescents. Pediatrics 2005;115:e561-5.

24. Souza EA, Barbosa Filho VC, Nogueira JA, Azevedo Junior MR. Physical activity and healthy eating in Brazilian students: a review of intervention programs. Cad Saude Publica 2011;27:1459-71.

25. Frainer DE, Adami F, Vasconcelos FA. Systematic review about methods of energy expenditure and energy intake in children and adolescents. Rev Bras Cineantropom Desempenho Hum 2008;10:197-205.

26. Foschini D, Araújo RC, Bacurau RF, de Piano A, de Almeida SS, Carnier J et al. Treatment of obese adolescents: the influence of periodization models and ACE genotype. Obesity (Silver Spring) 2010;18:766-72.

27. Dâmaso AR, Tock L, Tufik S, Prado WL, Stella SG, Fisberg M et al. Multidisciplinary treatment reduces visceral adiposity tissue, leptin, ghrelin and the prevalence of non-alcoholic fat liver disease (NAFLD) in obese adolescents. Rev Bras Med Esporte 2006;12:263-7.

28. Da Silva CA, Lima WC. Beneficial effect of short time physical exercise on the metabolic control of type 2 diabetes mellitus. Arq Bras Endocrinol Metab 2002:46:550-6. 